\title{
創発設計システムの構築に向けた大規模設計対象への事例適用*
}

\author{
佐藤 浩一郎*1, 氏 家 良 樹*2, 松 岡 由 幸*3
}

\section{Application of the Emergent Design System to a Large-Scale Design Object for Its Construction}

\author{
Koichiro SATO**, Yoshiki UJIIE and Yoshiyuki MATSUOKA \\ ${ }^{* 4}$ Graduate School of Science and Technology, Keio University, \\ 3-14-1 Hiyoshi, Kohoku-ku, Yokohama-shi, Kanagawa, 223-8522 Japan
}

\begin{abstract}
In the early design process, it is difficult to apply the conventional engineering design method from the necessity of the setting of the objective function. Therefore, in the past study, the emergent design system which is applicable for the early design process is proposed, and in an application to the design object without connectivity number in the form generation space and with number of elements of about $10^{4}$, effectiveness of deriving diverse design solutions using this system is indicated. In this study, we applied this system to a large-scale design object (a body in white) that has one or more connectivity number in the form generation space and number of elements of $10^{5}$ or more, and it contributed to construction of this system.
\end{abstract}

Key Words : Emergent Design, Diverse Design Solutions, Body in White

\section{1. 緒言}

設計過程は，一般に上流過程と下流過程に大別され る. 前者の上流過程に扔いては，概念設計や基本設計 が行われる，概念設計ではどのような人工物を設計す るかといら設計対象のコンセプトを決定し，基本設計 では概念設計で決定したコンセプトを実現するための 大まかな形状や構造の決定を行う。この上流過程にお いては，設計目標や条件が不明確であるため，大域的 な解探索により多样な設計解候補を導出する。後者の 下流過程においては詳細設計が行われる。詳細設計で は，基本設計で決定した形状・構造をもとに加工や組 み立て等を考慮し，最終的な設計解を導出する．下流 過程では，上流過程と比較して設計目標や条件が明確 であるため，最適化法 ${ }^{(1-5)}$ 等を用いることによって合目 的な唯一解を導出することが可能である，一方，上流 過程においては, 設計者の持つ経験や知識などを利用 して試行錯誤的に多様な設計解候補を導出するため, 設計者の経験や知識に依存してしまい，局所解に陥る 可能性がある，そのため，より大域的な解探索が可能 な手法が必要とされている，そこで，筆者らは設計上 流過程においても大域的な解探索が可能な, 創発の概

* 原稿受付 2008 年 8 月 4 日.

*1 正員, 慶應義塾大学大学院理工学研究科(画 223-8522 横浜 市港北区日吉 3-14-1).

*2 正員, 慶㗹義塾大学理工学部.

*3 正員, フェロ一, 慶應義塾大学理工学部.

E-mail: Koichiro_Sato@a7.keio.jp
念に基づく設計方法および設計システムの研究を進め てきた(6-9).

本報の研究の位置づけを図1に示す。過去の研究に おいて，大域的な解探索が可能な設計システムである 創発設計システムが提案されており，椅子の形状生成 への試行の結果, 強度を満足した多椂な形状が導出さ れることが確認されている( ${ }^{(8)}$. 前報(9)においては, 創 発設計システムの構築に向けて, 人工股関節ステムを 設計対象として本システムに適用を行った。この設計 対象の特徵は, 形状を生成する空間の位相幾何学にお ける連結数 $(C N)$ が 0 であり, 要素数が $10^{4}$ オーダー であった。ここで，連結数とは閉曲面に存在する穴の 数を表し, 本研究では形状生成空間に存在する穴の個 数を表している. 本システムを適用した結果, 質量と 最大相当応力について本システムと従来の最適化法に より得られた従来解を比較することにより, 従来解と 同等の強度を有し，かつ軽量化された多様な設計解が 導出された：この結果から本システムの多様な設計解 導出に対する有効性が示され, システム構築の一助と した。しかし，実際の設計問題への適用を考慮した場 合, $C N$ が 1 以上となる複雑な形状生成空間における 問題や，要素数のオーダーが $10^{4}$ より大きい問題等に 適用する必要があると考えられる。

本研究では, 創発設計システムを大規模設計対象に 適用を行う。本報における大規模設計対象とは, 形状 


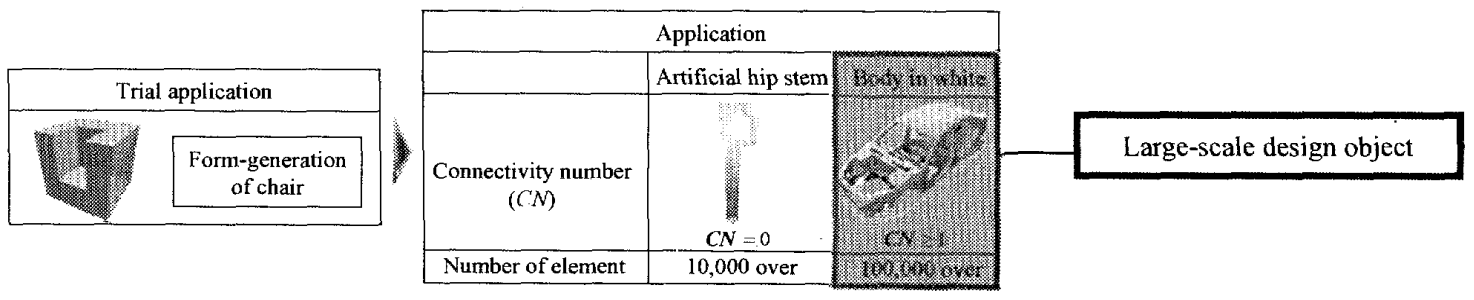

Fig.1 Position of this research

生成空間の $C N$ が 1 以上であり，さらに要素数のオー ダーが $10^{5}$ である設計対象を指す，設計対象としては， 車体骨格を選定し，本システムの適用を行う，そして， 本システムによる解と従来の最適化法による解の比較 を行う。そして，大規模設計対象に対する本システム の多様な設計解導出における有効性を示し，システム 構築の一助とする。

\section{2. 創発設計システム}

本章においては，多椂な設計解を導出することが可 能な創発設計システムの概要について述べる.

\section{$2 \cdot 1$ 創発と創発設計自然界においては，同一環境} 下においても多様な生物種が存在する. 生物学や生態 学の分野において，このような多様な生物種は，創発 過程により生み出されると考えられはじめた。北村(10) によれば，創発とは「自律的にふるまう個体（要素） 閒および環境との間の局所的な相互作用が大域的な秩 序を発現し(ボトムアップ), 他方, そのように生じた 秩序が個体のふるまいを拘束する（トップダウン）之 いう双方向の動的過程により, 新しい機能, 形質, 行 動が獲得されること」とされている。一方, 設計過程 と創発過程の類似性を見出すことができる，設計過程 における設計者やデザイナーの直観により設計案を導 き，ある基準以上の評価を有する設計案を発現する過 程は，創発過程にお污る，全体の特性に対して非明示 的な構成要素同士が相互作用を及ぼしあい全体の特性

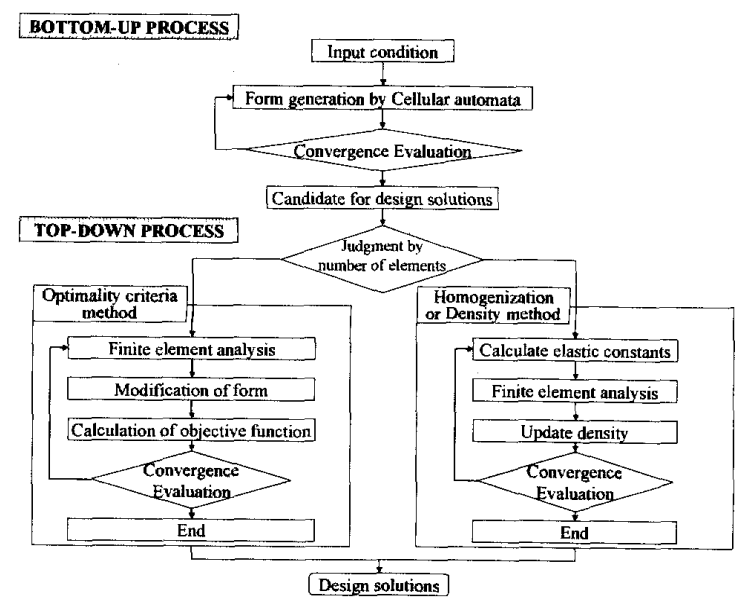

Fig.2 Emergent design system
を発現するボトムアップに類似している。また，設計 案の詳細部分が最適化される過程は，創発過程におけ る全体の特性により構成要素が拘束されるというトッ プダウンに類似している。このような類似性は，創発 の概念を設計に応用する可能性を示唆している，特に 設計上流過程においては，このボトムアップとトップ ダウンの両者が行われる傾向にある：このボトムアッ プとトップダウンの双方向性を有する「創発設計」が 行われることにより，新しくかつ多様な設計解候補が 導出されると考えられる。

$2 \cdot 2$ 創発設計システム前節で述べた創発設計に基 ぶく設計システムとして創発設計システムが提案され ている ${ }^{(6)}$. 本システムは, 多様な 3 次元形状を生成す る過程であるボトムアップ過程と，ボトムアップ過程 で得られた形状を最適化するトップダウン過程の 2 つ の過程により構成される.

システム図を図 2 に示す．ボトムアップ過程におい ては，セルラ・オートマトン（以下 CA と略記する） を用いて自己組織的に多様な形状の生成を行う。本シ ステムでは，ボクセルを用いて CAにおける要素を表 現している、また，CAにおける状態遷移ルールとし て，生物の多様性に起因する発生特性である誘導と頂 部支配を導入した，誘導とは，細胞が他の隣接細胞一 作用して，その隣接細胞を特定の形質へ変化させる特 性である、これを，注目要素の周辺から受ける近傍情 報ベクトル $v_{n}$ としてモデル化した（図 3(a)）。また， 頂部支配とは，頂部と呼ばれる個体発生を統制する支 配的な要素が，形態形成に影響を与えるという特性で ある。これを，頂部加ら注目要素へ影響寸る位置情報 バクトル $v_{p}$ としてモデル化した（図 3(b)).これによ り，頂部に近い要素ほど頂部の影響を強く受けるとい

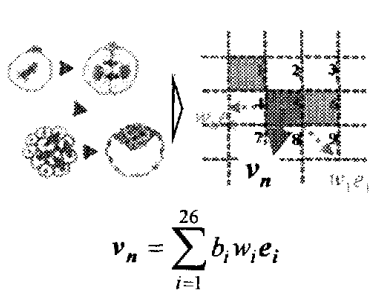

(a) Induction

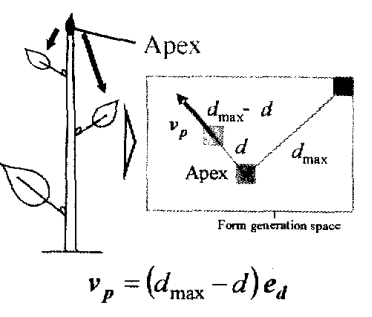

(b) Apical dominance
Fig.3 Input vector 
う性質を持つ，2つのベタトルを結合し，その合成比 率を $k$ と定義し，CAの入力ベクトルを次式のように 設定した。

$$
v_{\text {in }}=k v_{n}+(1-k) v_{p} \quad(0 \leq k \leq 1)
$$

$k$ の值は，誘導と頂部支配の作用の合成の割合を調整 可能なパラメータである. 式(1)において $k$ の值が 1 に 近ければ誘導による影響が強く, 注目要素の周囲に存 在する要素から様々な方向の作用を受けることになり 塊状の形状が生成される傾向がある. 一方, 式(1)にお いてkの值が $0 に$ 近ければ頂部支配による影響が強く， 常に頂部から同一方向の作用を受けることになり棒状 や板状の形状が生成される傾向がある. ボトムアップ 過程における入力パラメータは合成比率 $k$ の他に頂部 位置, 形状生成空閒, 要素サイズ, 初期要素, 発生世 代数，および評価項目がある。頂部位置とは，頂部支 配の作用の中心となる位置である. 形状生成空間とは, 要素の生成範囲を示す空間である。要素サイズとは, 形状を構成するボクセルの大きさである。初期要素と は，CAにおいて形状生成を開始する要素であり，設 計対象において要素が必ず存在する部位を初期要素と することが望ましい，発生世代数とは，形状を更新す る回数である。また，評価項目とは，ボトムアップ過 程において満たすべき項目である.

トップダウン過程においては，ボトムアップ過程に より導出された多様な形状について，それぞれを設計 者が定める条件の下で最適化する. 最適化法として, 本システムでは最適性規準法と均質化法もしくは密度 法による位相最適化が実行可能である。本研究では, 均質化法と比較して設計変数が少なく計算效率に優れ ている密度法による位相最適化を実行することとした。 密度法による位相最適化は，材料の弾性剛性が密度の べき乗に比例すると仮定し，各要素の密度を設計変数 として最適な材料分布を求める方法である ${ }^{(11)}$. トップ ダウン過程における入力パラメータには, 荷重条件や 拘束条件のような力学条件，目的関数および制約関数 がある。トップダウン過程においては，以上のパラメ

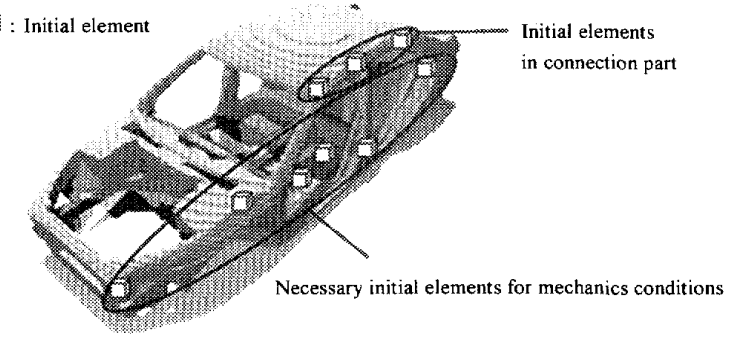

Fig.4 Form generation space of BIW and initial elements
一タを用いて，実際に設計対象に求められる条件を入 力する。

\section{3. 創発設計システムの大規模設計対象への適用}

本章では，2 章において示した創発設計システムを 車体骨格設計入適用する。また，多様な設計解導出に 対する有效性を検証する。

3.1 大規模設計対象過去の研究において形状生成 空閒の $C N$ が 0 であり，要素数が $10^{4}$ オーダーである 設計条件として人工股関節ステム形状に適用を行った。 しかし，実際の設計に本システムを用いる場合には， $C N$ が 1 以上であり，さらに多くの要素数を有する設 計対象に適用し, 多様な設計解導出に対する有効性を 示寸必要がある。そこで, 本研究においては，大規模 設計対象（形状生成空間の $C N$ が 1 以上であり，形状 を構成する要素数のオーダーが $10^{5}$ である設計対象) に本システムを適用し，そのような設計対象として車 体骨格を選定した。

\section{$3 \cdot 2$ ボトムアップ過程}

$3 \cdot 2 \cdot 1$ パラメータ設定本研究における形状生成空 間としては，通常の車体骨格を拡張した形状とし，図 4 のように設定した。また，ボクセルの大きさは一辺 $15 \mathrm{~mm}$ とし, 総要素数は約 23 万個となった. 初期要素 は，生成される形状す心゙てに存在するため, 設計上必 要な部位に配置寸ることが適当である，本研究におい ては，構造上要素が必要である各ピラーとルーフとの 接合部とトップダウン過程において入力する荷重点の 部位に初期要素を図 4 のように配置した。発生世代数 が増加すると形状の体積も増加することになる．本研 究では要素数 20 万個以上であるため, 過去の研究(6-9) のように数値を設定せずに発生が収束した場合に発生 世代数を停止することとした．評価項目は，トップダ ウン過程における力学解析の実行を考慮して, 複数箇 所から生長する要素同士が一続きになっていることと した．頂部は，図 5 に示すような前後搭乗者の着座位 置，頭部位置および脚部位置に設定した。合成比率は 0.1 から 0.9 まで 0.1 ずつ変化させて形状生成を行うこ ととした.

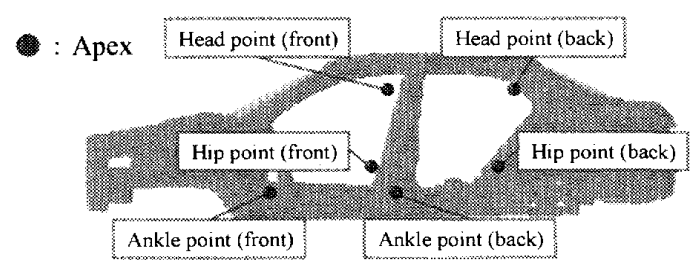

Fig.5 Position of apexes 

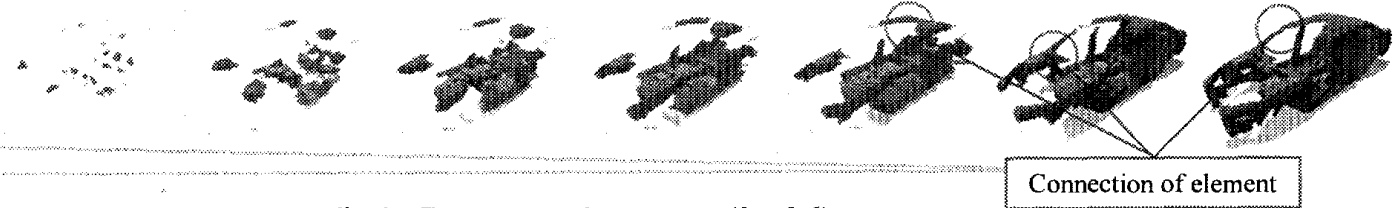

Fig.6 Form generation process $(k=0.6)$

3.2 .2 ボトムアップ過程の実行結果 設定したパラ メータでの形状生成の様子と導出された形状の一例を 図 6 と図 7 に示す. 複数の初期要素から生長した要素 同士の繋がり方が各形状で異なり，ルーフの前面が大 きく開いている形状やフロント部が結合していない形 状など，それぞれ特徽が異なる形状が導出された。合 成比率 $k$ の值が低いと頂部支配による位置情報心゙クト ルの作用が大きくなるため, 形状生成が抑制され，各 初期要素から発生した要素同士が慗がりにくくなり， 評価項目を満たさなくなるため，合成比率 $k$ が 0.6 末 満では形状が導出されなかった.この結果については, 5 章において考察を行う.

\section{$3 \cdot 3$ トップダウン過程}

3.3.1 荷重条件と材料特性值の設定本研究におら以 ては，最適化に用いた力学条件を図 8 のように設定し た。車体骨格の据り㓮性，曲げ剛性，エンジンルーム 剛性，ピラー横剛性の 4 つの剛性に関わる荷重条件を それぞれ設定した、最適化の際に用いた材料は炭素鋼 とし，弹性係数上ポアソン比はそれぞれ $210 \mathrm{GPa}, 0.3$ と設定した。また，一般的なホワイトボディ設計に従 い，ドアやエンジン等を取り付けていない状態で解析 を行った。

3.3.2 目的関数および制約条件本研究では, 目的関 数索剛性である平均コンプライアンス $C$ ，制約条件を ボトムアップ過程で導出された形状の質量の $10 \%$ 以 下になるように設定した。密度法を用いた位相最適化 問題は次式のように定式化される(11).

$$
\begin{aligned}
& \min _{\rho \in L}[C(\rho)] \quad C(\rho)=d^{T} \boldsymbol{K}(\rho) d \\
& L=\left\{\rho \mid 0 \leq \rho_{i} \leq 1 \quad(i=1, \cdots, N), \sum_{i=1}^{N} \rho_{i} \leq m_{s}\right\}
\end{aligned}
$$

ここで, $\boldsymbol{\rho}$ は設計変数 $\left\{\rho_{1}, \rho_{2}, \cdots, \rho_{N}\right\}$ で $\rho_{i}$ は $i$ 番目 要素の密度比を表し, $N$ は有限要素数である.また, $\boldsymbol{d}$ は節点変位ベクトル， $\boldsymbol{K}$ は全体剛性マトリックス， $\boldsymbol{L}$ は与えられた条件を満たす許容設計变数の集合， $m_{s}$ は 密度比の制約值であり ${ }^{(11)}$, 本研究では全要素の密度比 を 1 とした場合の $10 \%$ とした。

3.3.3 トップダウン過程の実行結果 ボトムアップ 過程において導出された形状に対して密度法による位 相最適化を実行した結果の一例を図 9 に示す。本シス テムにより得られた解の特徴として，以下のようなこ

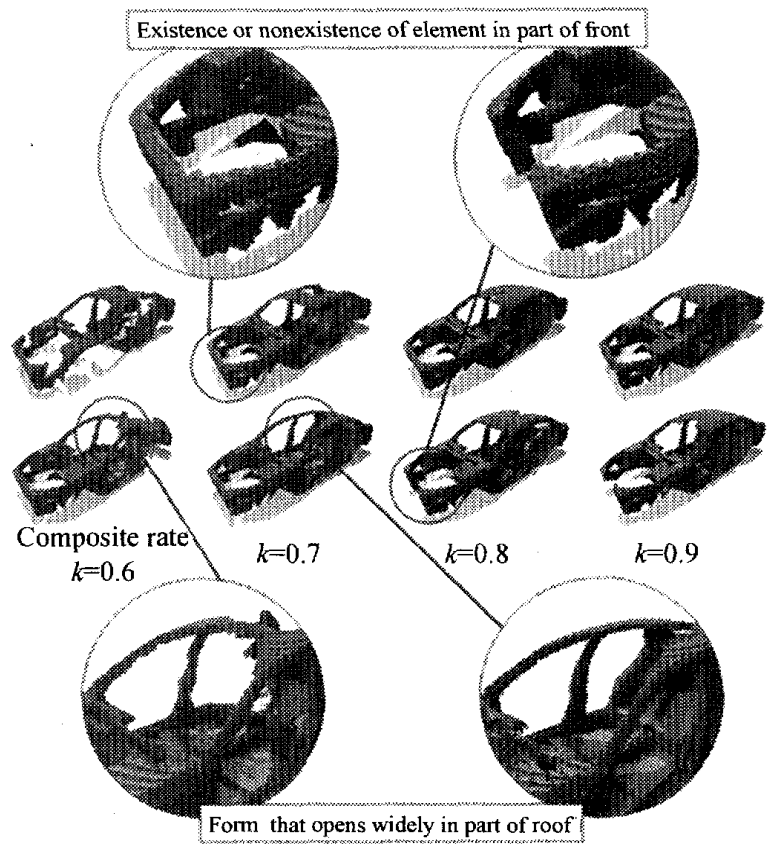

Fig.7 Examples of design candidates by bottom-up process

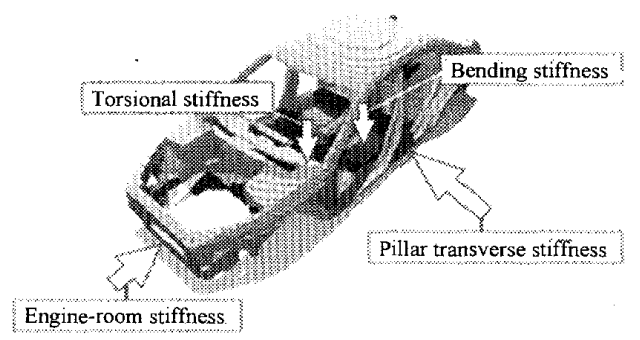

Fig.8 Loading conditions

とが挙げられる。

キャビン周辺の要素は最適化法によって削除されに くいが，ボトムアップ過程で導出された各形状はキャ ビン周辺に異なる形状を有しているため，その特徽を 残しつつ形状の最適化が行われていることが確認でき る、キャビン周辺の要素が削除されにくいのは, 複数 の荷重条件が作用することで各荷重条件に対する剛性 を保つためと考える。車体前後部において要素が多く 削除されるのは衝突に相当する荷重が伝達している要 素は必要となるが，それ以外の車体前後部の要素につ いては必要でないため削除される。このような特徴か らキャビン周りでの位相の発生や荷重伝達の異なる多 様な設計解が導出されたことが確認できた。このよう にボトムアップ過程において，初期形状が異なる多様 な形状を生成し，トップダウン過程において多様な初 
期形状に対して最適化を行うことによって多様な設計 解を導出することが可能である。

\section{4. 従来の最適化法との比較}

本システムにより導出された設計解の有効性を検証 するために従来の手法で導出された設計解と比較を行 った，従来解とは，形状生成空間を要素で充填した形 状を初期形状として密度法による位相最適化を行った 形状であり，ボトムアップ過程を経ずトップダウン過 程による最適化のみを行った設計解である.図 10 に従 来解および本システムにより導出された解の形状，質 量および各力学条件に対する最大相当心力の值を示す. 最適化法のみを実行した図10(a)の従来解は, 初期形状 と比較して，特に車体正面および背面部分において大 きく要素が削除され，フロアの前後部にも要素の削除 が確認できる.さらに,この従来解と比較して, 図 $10(\mathrm{~b})$ の設計解では(1)-1 のフロント部分, 図 10(c)の設計解で は(2)-1のフロア部分の形状が異なっていることが確認 できる. 図 10(b)の本システムによる解は，ピラー横剛 性に関しては従来解とほぼ同等である。また，エンジ ンルーム剛性に対寸る最大相当応力は従来解よりもや や高い值を示しているものの，曲け剛性に対する最大 相当応力においては従来解より最大相当応力が低い值 を示している.この要因としては,図 10 の(1)-2 や(1)-3 に示すように (b) の設計解はダッシュパネル付近やキ ヤビン後方部の補強が考えられる。この他にも，図 10(a)の(1)-4の部分では, 従来解ではキャビン後方部分 の荷重を受ける部材に梁を渡して補強しているのに対 して図 10(b)の(1)-4 の設計解は部材を太くして補強し ており, 異なる形状特徵を有している.また, 図 10(c)
の本システムによる解においても従来解と比較すると 曲げ剛性の最大相当応力の值はやや高い值を示してい るが，ピラー横剛性については低い值を示している. この要因としては, 図 10(c)の(2)-2に示寸ようにピラー 横剛性の荷重を分散するようなルーフ部分の形状を有 しているからと考えられる，以上のように本システム を用いることにより，従来解よりも最大で 16\%軽量化 され，同等もしくはそれ以上の強度を持つ設計解を導 出できる可能性が示された，以上の結果から，大規模 設計対象に対する本システムの多様な設計解導出に対 する有効性が示された．今後，導出された設計解の構 造上の特徴を踏襲しながら最終の設計解に到達するべ く, 形状最適化などのより詳細な検討を行っていく必 要がある。

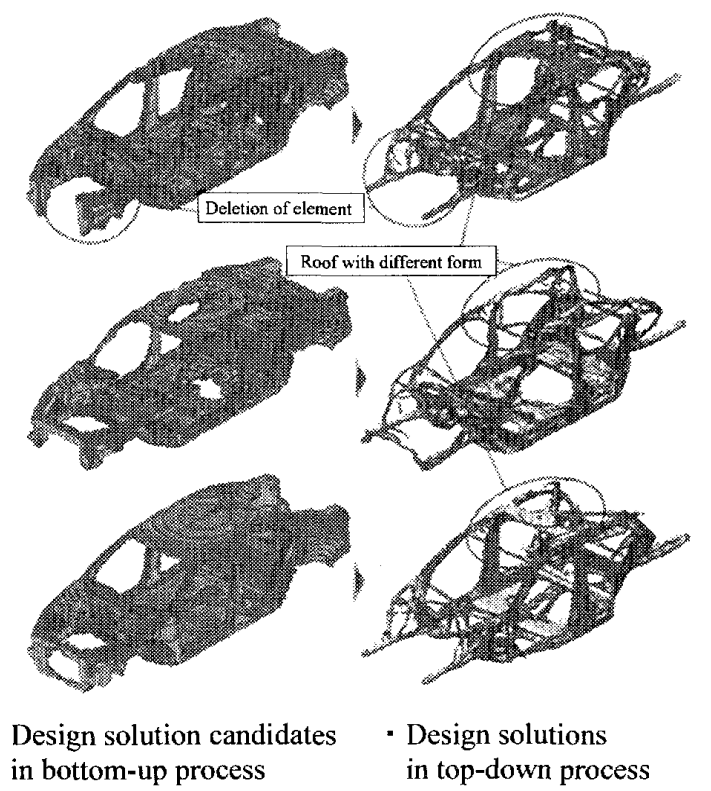

Fig.9 Design solutions by Emergent design system

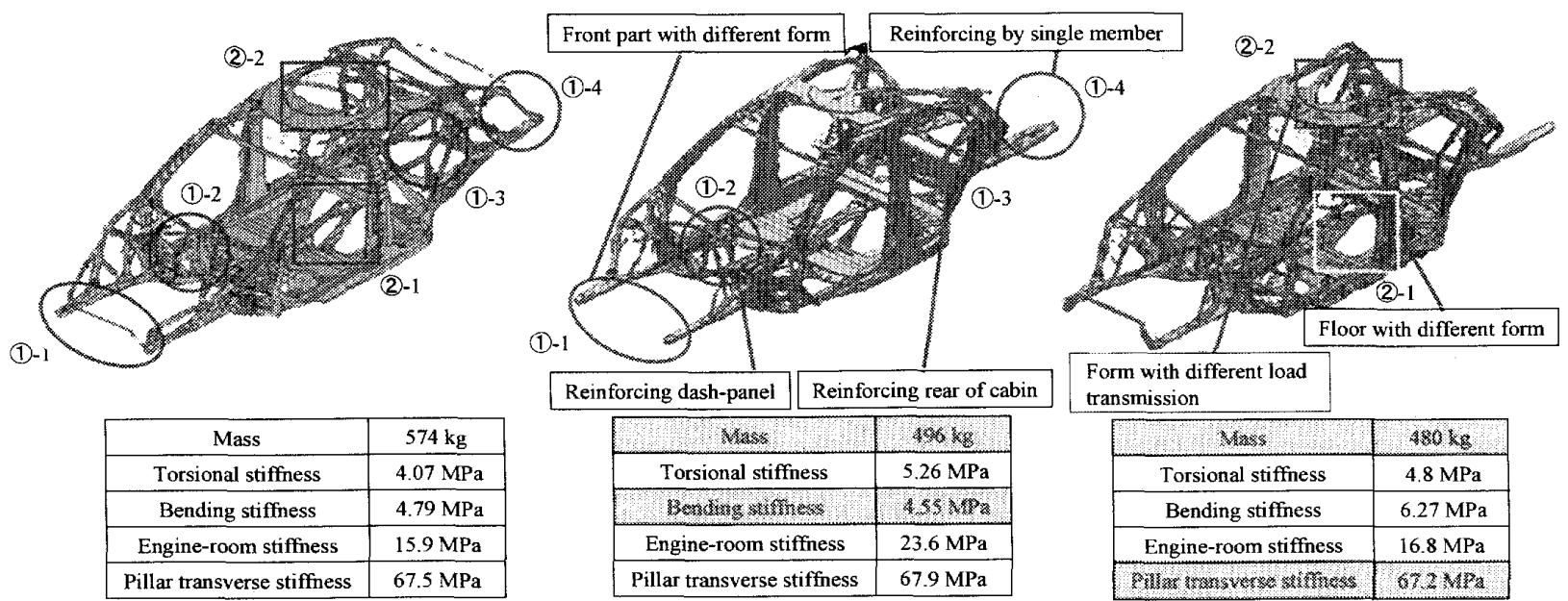

(a) Conventional design solution

(b) Design solution obtained by the form generation system ( I ) (c) Design solution obtained by the form generation system (II)

Fig.10 Comparison between mass and maximum equivalent stress 


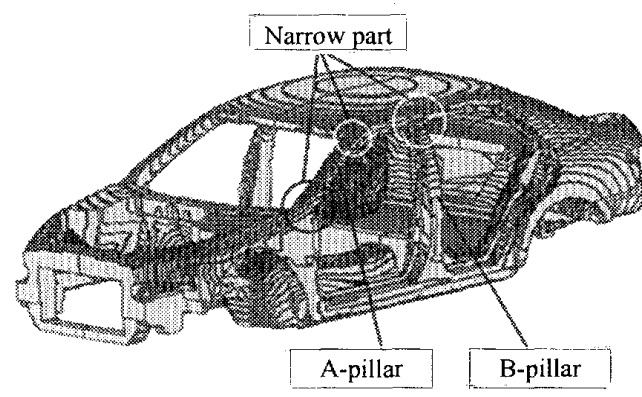

Fig.11 Narrow part in form generation space

\section{5. $C N$ の有無による形状生成傾向の変化に関す る考察}

図 11 より, A ピラーやB ピラーのように形状生成空 間の幅が狭い部分の存在が確認できる。これらの形状 生成空間の特徴は, 前報 ${ }^{(9)}$ の適用事例では存在しなか った。この特徴の違いから以下のことが考えられる。

$C N$ が 1 以上であることで形状生成空間が狭くなる ような部分においては，誘導の作用が小さい場合には 形状生成を抑制する頂部の作用が大きくなるため，形 状が生長しにくいことが挙げられる。また，形状が生 長しにくいために, 複数ある初期要素から生長した要 素同士が繋がりにくくなり形状が導出されにくいこと も考えられる。これは 3 章で示したように合成比率 $k$ が 0.6 未満の場合に形状が導出されないということか らも確認できる，以上のことから，CNが 1 以上のと きに形状生成空間が狭くなる場合には誘導の作用が有 効であることが考えられる。これは，誘導の作用によ つて，ピラー等の形状生成空間が狭い部分に掠いても 形状生成空間に沿うように要素が生長していくことが 可能であるためである。しかし，誘導の作用はこれら のような空間の幅が狭い設計対象に対して有効である が，頂部支配の作用が小さくなるため，ボトムアップ 過程において異なる位相を有するような多様な形状は 導出されにくい，そのため，誘導の作用が大きい場合 でも多様な形状を導出するための方法が望まれる。

\section{6. 結言}

本報では，形状生成空間のCN が 1 以上であり，要 素数のオーダーが $10^{5}$ である大規模設計対象に創発設 計システムを適用し，本システムと従来の最適化法に よる解の比較を行った。 その結果, 大規模設計対象に 対する本システムの多様な設計解導出の有効性を示し， システム構築の一助とした。本研究の成果を以下に示 寸。
(1) 形状生成空間のCN が 1 以上で要素数が多い設計 対象においても本システムを用いることにより 異なる位相を有する多様な設計解が導出された。

(2)本システムにより導出された設計解と最適化法の 文を用いた従来解を最大相当応力で比較すると 本システムで導出された設計解は，従来解に対し て最大 $16 \%$ 軽量化され，4つの剛性において同等 かそれ以上の剛性を有した。

（3）(1)，(2)より，大規模設計対象に対する本システ ムの多様な設計解導出に対する有効性が示唆さ れた。

(4) 形状生成空間の幅が狭い場合誘導の作用が形状導 出に対して有効であることが確認された。

（5）誘導の作用が大きい場合，ボトムアップ過程にお いて位相が異なる多様な形状は導出されにくく なるため，誘導の作用が大きい場合でも多様な形 状を導出するための方法の必要性を確認した。

なお，本論文においては多様な形状特徴を有する設 計解が導出されている. 今後，これを踏襲した最終的 な設計解を導出するためのシステム開発が必要である。

\section{文 献}

(1) Bensøe, M., Kikuchi, N., Generating Optimal Topologies in Structural Design Using a Homogenization Method, Computer Methods in Applied Mechanics and Engineering., 71 (1988), 197-224

(2) Diaz A. R., Belding B., On Optimum Truss Layout by a Homogenization Method, Trans. ASME, J. of Mech. Des., 115(1993), 367-373.

(3) Kumar, AV., Gossard, DC., Synthesis of Optimal Shape and Topology of Structures, Trans. ASME, J. of Mech. Des., 118 (1996), 68-74

(4) Ishii, K., et al., A Topology Optimization by using the Frame Based Unit-Cell, JSME, 67-654, C (2001), 499-506

(5) Hujii D., et al.,Topology Optimization of Compliant Mechanisms Using the Homogenization Design Method, Struct.Constr.Eng., AIJ, 528 (2000), 99-105.

(6) Inoue, M., Matsuoka, Y., Evolutionary Form-Generation System Based on Emergence, The Science of Design, 48-2 (2001), 1-8

(7) Matsuoka, Y., Fujii, T., Form-Generation Method Applying Properties in the Developmental Process of Organism Generating the Morphological Diversity, The Science of Design, 49-3 (2002), 93-102.

(8) Matsuoka, Y., Inoue, M., System for Obtaining Diverse Design Solutions Based on Emergence, Japan Society for Design Engineering, 38-8 (2003), 411-420.

(9) Sato, K., et al., Construction of an Emergent Design System by Application to Development of the Artificial Hip Stem, Japan Society for Design Engineering, 43-2 (2008), 93-100.

(10) Kitamura S., Systems-Toward a New Paradigm for Artificial Systems. Toward System Theory of Function Emergence, 35-7 (1996), 492-495.

(11) Hujii D., et al., Topology optimization of structures using the voxel finite element method. Japan Society for Computational Engineering and Science, 2(2000), 87-94. 